\title{
INDIGENOUS PEOPLES AND LOCAL COMMUNITY TENURE IN THE INDCS Status and Recommendations
}

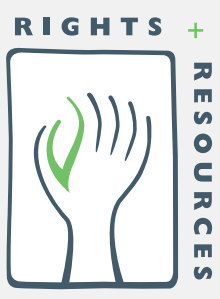

April 2016
In December 2015, representatives of governments, civil society organizations, Indigenous Peoples' groups, and the private sector met in Paris for the $21^{\text {st }}$ Conference of Parties (COP 21) of the United Nations Framework Convention on Climate Change (UNFCCC). The aim of this meeting was to determine a global path forward that would limit the rise in global temperature to no more than 2 degrees Celsius above pre-industrial levels and allow countries to reach peak greenhouse gas emissions as soon as possible. ${ }^{1}$

With its recognition of the crucial role that forests play in achieving targeted emissions reductions, the Paris Agreement marks a major turning point in the global struggle to combat climate change. Yet, the final Agreement lacks key considerations for the Indigenous Peoples and local communities (IP/LCs) who have customary rights to a large portion of the world's remaining tropical forests, as well as millions of hectares of degraded forests that could capture additional carbon through restoration. Although Indigenous Peoples and civil society groups from around the world advocated throughout the negotiation process that clear provisions securing IP/LC land tenure would be essential components of any successful and equitable climate agreement, ${ }^{2}$ text on the rights of IP/LCs was limited to the preamble. Ultimately, the Paris Agreement failed to take into account the significance of community land rights and community-based natural resource management (CBNRM) for realizing its ambitious goals.

This brief presents a review of 161 Intended Nationally Determined Contributions (INDCs) submitted on behalf of 188 countries $^{3}$ for COP 21 to determine the extent to which Parties made clear commitments to strengthen or expand the tenure and natural resource management rights of IP/LCs as part of their climate change mitigation plans or associated adaptation actions. ${ }^{4}$ Of the 161 INDCs submitted, 131 are from countries with tropical and subtropical forests. ${ }^{5}$
Rights and Resources Initiative Supporting forest tenure, policy and market reforms

rightsandresources.org

\section{RRI PARTNERS}

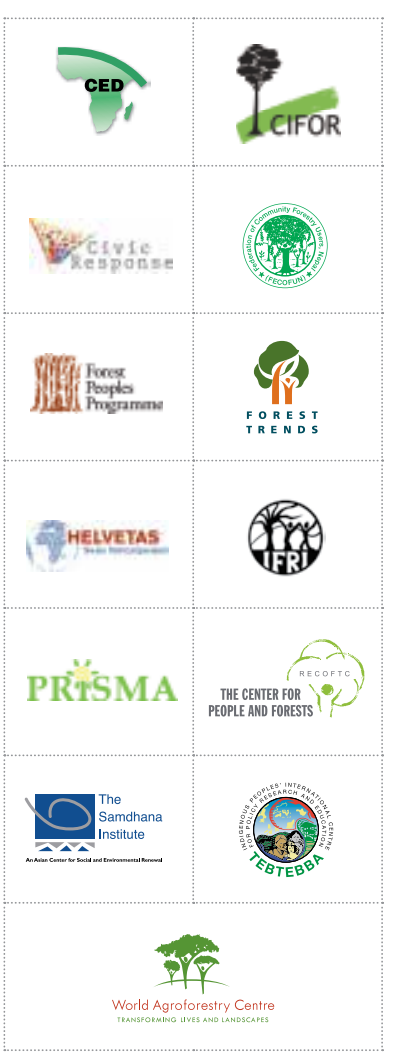




\section{Why IP/LC Tenure as a Strategy for Climate Change Mitigation?}

Indigenous Peoples and local communities play an essential role in protecting forests and preventing changes in land use and land cover, both of which are important for reducing greenhouse gas emissions. Emissions from agriculture, forestry, and other land uses represent almost a quarter of anthropogenic greenhouse gas emissions from activities such as deforestation, forest degradation, and biomass burning on both forest and agricultural lands. ${ }^{6}$ Forests in particular act as an enormous carbon sink, the storage potential of which could increase by as much as 3 to 5 gigatons of carbon per year if reforestation efforts were encouraged. Thus, halting deforestation and land conversion in tropical forests is one of the most effective and immediate steps the global community can take to reduce emissions. ${ }^{7}$

Conservative estimates suggest that 20 percent of the aboveground carbon stored in the world's tropical forests is found in territories claimed by the Indigenous Peoples and local communities of Mesoamerica, Amazonia, the Democratic Republic of the Congo, and Indonesia. ${ }^{8}$ However, only a fraction of the lands claimed by IP/LCs in these regions is legally recognized by national governments as community-owned or managed. ${ }^{9}$

Research shows that when IP/LCs have legally recognized and enforceable rights, both deforestation and carbon emissions can be significantly lower compared with areas outside of community forests. For example, community and indigenous forests in Brazil store 36 percent more carbon per hectare, and emit 27 times less carbon dioxide from deforestation than forests not under community control. ${ }^{10}$

Similarly, while data on community grassland management is more limited than that on community forests, evidence suggests that community-based systems of grassland management, such as migratory pastoral and agro-pastoral systems, tend to support

\section{Box 1: Findings and Recommendations}

Only 21 INDCs representing 13 percent of the world's tropical and subtropical forest area included clear commitments to implement community-based tenure or natural resource management strategies as part of their climate change mitigation plans or adaptation actions, and only one set a measurable target for the expansion of IP/LC tenure rights. This illustrates the significant gap between the recognition that securing IP/LC land rights is fundamentally important for achieving both sustainable development and climate change targets, and the willingness of states to implement needed reforms. To close this gap, the following actions should be taken:

- Parties should monitor the development and resulting climate benefits of community-based natural resource management and IP/LC tenure systems, and share their experiences and lessons learned at the global stocktake in 2018.

- Countries should be encouraged to include specific, measurable, and robust tenure and natural resource rights for IP/LCs in national climate change mitigation strategies by 2020.

- Bilateral and multilateral climate financing mechanisms should increase and expand dedicated funding streams for tenure reform, and secure access to technical assistance to help Parties achieve such ends.

- The leading platforms funding or supporting land- and forest-based mitigation strategies must recognize IP/LC tenure rights in their guidelines and safeguards as a necessary prerequisite for effective, equitable, and accountable REDD+ implementation. 
greater carbon storage than ranching or sedentary models. ${ }^{11}$ In Mongolia, for instance, a 10-year study conducted in the Gobi Desert found that grasslands managed by communities contained 15 percent more plant biomass than those not managed by communities. ${ }^{12}$

Crucially, securing IP/LC tenure can yield benefits worth far more than the initial investment and maintenance costs. In addition to climate change mitigation and the protection of other ecosystem services, such as the preservation of biodiversity and maintenance of watershed functions, securing community land rights also yields important social and economic benefits. This is exemplified by nine community forest concessions in the Maya Biosphere Reserve in Guatemala, where the annual cost per hectare of securing community tenure is estimated to be approximately one-tenth of the benefits realized over time when communities have tenure security. ${ }^{13}$

\section{What are INDCs?}

In advance of COP 21, Parties to the framework convention were invited to submit INDCs outlining national plans for reducing greenhouse gas emissions across all sectors. The 2014 Lima Call for Climate Action established the pledge and review process by which countries set out to define their initial commitments toward combatting climate change. The guidelines for these commitments were intentionally broad to provide countries with the flexibility to tailor their climate change mitigation strategies to their respective national needs and conditions. However, this resulted in significant inconsistencies across country submissions in terms of reference points, methodological approaches for estimating emissions, and implementation, creating significant challenges for subsequent comparison, monitoring, and evaluation processes. ${ }^{14}$

Though INDCs are not formally annexed to the Paris Agreement, Decision 1/CP.21 requires Parties to prepare, communicate, and pursue the domestic mitigation measures stated in their INDCs. Unless decided otherwise by the Parties themselves, submitted INDCs will become the first Nationally Determined Contribution (NDC) for all Parties that join the Agreement. These can be adjusted at any time, but must be revised every five years with visible progress in the level of anticipated emissions reductions.

Parties to the Agreement will also participate in a global stocktaking process in 2018 to assess progress made toward reducing emissions; this will inform the development of NDCs submitted by 2020. This global stocktake will be organized to maintain the pace of emissions reduction commitments in each successive NDC cycle. In support of this process, the Ad Hoc Working Group on the Paris Agreement was also established to provide additional guidance as required.

\section{Key Findings}

The process of strengthening the INDCs through subsequent NDC commitments presents a unique opportunity for countries to incorporate strong recognition of IP/LC land tenure into national climate change mitigation strategies and associated co-benefits resulting from Parties' adaptation actions and/or economic diversification plans.

However, we found that only 21 countries representing 13 percent of tropical and subtropical forest area ${ }^{15}$ made a clear commitment to implement IP/LC tenure 
FIGURE 1 Countries that made clear commitments to strengthen or expand IP/LC tenure and natural resource management rights in their INDCs

\begin{tabular}{|c|c|c|}
\hline Bangladesh & Ethiopia & Nigeria \\
\hline Bolivia & Gambia & Senegal \\
\hline Burkina Faso & Ghana & Sudan \\
\hline Cambodia & Guatemala & Tanzania \\
\hline Cameroon & Mongolia & Togo \\
\hline Chad & Namibia & Uganda \\
\hline Djibouti & Nepal & Zambia \\
\hline
\end{tabular}

security or CBNRM objectives in their INDC submissions (see Figure 1). This represents only 16 percent of the countries with tropical and subtropical forests that submitted INDCs.

Importantly, many of the largest forested countries with high rates of deforestation — such as Brazil and Indonesia ${ }^{16}$ — did not include commitments to expand IP/LC tenure or natural resource management in their INDCs. Moreover, just 17 of the 64 UN-REDD Programme Partners clearly committed to implementing IP/LC tenure or natural resource management in their climate change mitigation strategies. ${ }^{17}$

Among countries that recognized a clear role for IP/LC tenure and natural resource management rights in their INDCs, African countries were most strongly represented at 71 percent. Zambia, for example, intends to implement Community Forest Management, Joint Forest Management, and Participatory Forest Management approaches as part of its contribution toward mitigating climate change. Furthermore, Zambia will strengthen the implementation of its decentralization policy, which will empower local communities as decision makers. ${ }^{18}$ Only 19 percent of the INDCs clearly committing to implement IP/ LC tenure and CBNRM in their climate change mitigation strategies were submitted by Asian countries, and only 10 percent by Latin American countries.

Only Cambodia set a tangible target for expanding IP/LC tenure rights in the text of its INDC. Cambodia explicitly committed to an expansion of community-based tenure through the reclassification of 2 million hectares of forest as Community Forests. If carried out, this action would designate 21 percent of Cambodia's forested areas for Indigenous Peoples and local communities_-almost 10 times the area of Community Forests recognized in 2013. ${ }^{19}$

Opportunities to increase the participation of IP/LCs in land management were mentioned in at least five additional INDCs. However, commitments to strengthening IP/LC land rights were either absent or unclear in the remaining 135 submissions. For example, the Central African Republic indicated it would "promote urban, suburban, and community forestry." ${ }^{20}$ Such vague and noncommittal statements were not considered strong enough to encourage tenure security objectives. As the Alliance for Land Rights Now makes clear, concrete goals in the INDCs are essential if the global community wishes to see real advancement in Indigenous Peoples' and local communities' land rights as a priority climate change mitigation strategy prior to $2020 . .^{21}$ 


\section{Indigenous Peoples' and Local Communities' Tenure Security and the Post-Paris Agenda}

Although a handful of countries can be commended for including strong language on community-based tenure or natural resource management in their current INDCs, the majority of countries in the world's most densely forested regions-such as Indonesia, the Congo Basin, and Amazonia — are not building on the crucial role that Indigenous Peoples and local communities play in protecting these valuable natural resources. Given the critical importance of community-based tenure for achieving both sustainable development priorities and the ambitious goal of the Paris Agreement to limit global temperature rise to 1.5 degrees Celsius above pre-industrial levels, the near absence of measurable targets for improving the recognition of IP/LC land rights in some of the most important carbon land-sinks in the world is alarming. Recognizing further that the carbon storage capacity of forests can be significantly increased if properly managed and restored, securing IP/LC land rights constitutes one the most cost-effective and equitable solutions to fulfilling the ambitious goals of the Paris Agreement, which calls on all Parties to pursue actions on the basis of equity, and in the context of sustainable development and efforts to eradicate poverty (Article 4.1). Evidence drawn from the existing INDCs points to the critical need for immediate and robust actions by all Parties to undertake the following steps:

- Parties should monitor the development and resulting climate benefits of CBNRM and community-based tenure systems and share their experiences and lessons learned at the global stocktake in 2018.

- Countries should be encouraged to include specific, measurable, and robust tenure and natural resource rights for Indigenous Peoples and local communities in national climate change mitigation strategies by 2020.

- Bilateral and multilateral climate financing mechanisms should increase and expand dedicated funding streams for tenure reform, and secure access to technical assistance to help Parties achieve such ends.

- The leading platforms funding or supporting land-and forest-based mitigation strategies (such as UN-REDD, FCPF, the Carbon Fund, FIP/DGM, the GCF, and associated bilateral initiatives) must recognize tenure rights in their guidelines and safeguards as a necessary prerequisite for effective, equitable, and accountable REDD+ implementation. 


\section{Endnotes}

1 UNFCCC. 2015. The Paris Agreement (FCCC/CP/2015/L.9/Rev.1). United Nations Framework Convention on Climate Change. Available at: https://unfccc.int/resource/docs/2015/cop21/eng/109r01.pdf.

2 Tauli-Corpuz, Victoria. 2015. Removing Rights for Indigenous Peoples Places Forests, Climate Plan at Risk. Statement from Paris, COP 21. United Nations Special Rapporteur on the Rights of Indigenous Peoples. Available at: http://unsr.vtaulicorpuz.org/site/index.php/en/statements/106-statement-cop21.

3 The European Union submitted a joint INDC representing all 28 member states. Iraq and Kuwait each submitted INDCs, but these documents were only available in Arabic and RRI was unable to determine the extent to which community-based tenure or natural resource management was included in the texts.

4 RRI determined that Parties had made a "clear commitment to strengthen or expand IP/LC tenure or natural resource management rights" if they explicitly discussed the strengthening or expansion of IP/LC tenure rights, acknowledged the continuation of an existing national program addressing IP/LC tenure or natural resource management, or otherwise made a clear commitment to community-based management of natural resources. INDCs were not considered to have met these criteria if they only discussed IP/LC rights in terms of participation or promotion, or if tenure and natural resource management strategies were not clearly identified as communitybased in nature.

5 FA0. 2015a. Global Forest Resources Assessment Forest Land Use Data Explorer (FLUDE), Forest Data and Characteristics. Food and Agriculture Organization of the United Nations, Rome. Available at: http://www.fao.org/ forest-resources-assessment/explore-data/flude/en/.

6 IPCC. 2014. Climate Change 2014: Synthesis Report. Contribution of Working Groups I, II, and III to the Fifth Assessment Report of the Intergovernmental Panel on Climate Change. Core Writing Team, R.K. Pachaauri and L.A. Meyer eds. Intergovernmental Panel on Climate Change, Geneva, Switzerland. 46. Available at: https://www. ipcc.ch/pdf/assessment-report/ar5/syr/SYR_AR5_FINAL_full_wcover.pdf.

7 Houghton, Richard A. 2013. The emissions of carbon from deforestation and degradation in the tropics: Past trends and future potential. Carbon Management. Available at: https://www.researchgate.net/profile/Richard Houghton3/publication/269846162_The_emissions_of_carbon_from_defordeforest_and_degradation_in_the_ tropics_Past_trends_and_future_potential/links/5630d15308ae2df441bb7fb7.pdf?inVieinV=0\&pdfJsDownload $=0 \&$ origin=publication_detail.

8 The Woods Hole Research Center and Environmental Defense Fund. 2015. Tropical Forest Carbon in Indigenous Territories: A Global Analysis. Report prepared for UNFCCC COP21. The Woods Hole Research Center and Environmental Defense Fund. Available at: https://www.edf.org/sites/default/files/tropical-forest-carbon-inindigenous-territories-a-global-analysis.pdf.

9 RRI. 2014. What Future for Reform? Progress and slowdown in forest tenure reform since 2002. Rights and Resources Initiative, Washington, D.C.

${ }^{10}$ WRI and RRI. 2014. Securing Rights, Combating Climate Change. World Resources Institute and Rights and Resources Initiative, Washington, D.C.

${ }^{11}$ FA0. 2009. Review of evidence on drylands pastoral systems and climate change: Implications and Opportunities for mitigation and adaptation. Food and Agriculture Organization of the United Nations, Rome. C. Neely, S. Bunning, and A. Wilkes, eds. Available at: http://www.fao.org/3/a-i1135e.pdf.

${ }_{12}$ Craig Leisher, Sebastiaan Hess, Timothy Boucher, Peter Van Beukering, and M. Sanjayan. 2012. Measuring the Impacts of Community-based Grasslands Management in Mongolia's Gobi. PLoS One. 7(2): e30991. Available at: http://www.ncbi.nlm.nih.gov/pmc/articles/PMC3270020/.

${ }^{13}$ Gray, Erin, Peter G. Veit, Juan Carlos Altamirano, et al. 2015. The Economic Costs and Benefits of Securing Community Forest Tenure: Evidence from Brazil and Guatemala. World Resources Institute, Washington, D.C. Available at: http://www.wri.org/sites/default/files/15_WP_CLUA_Forest_Tenure.pdf.

14 Aldy, Joseph E. 2015. Evaluating Mitigation Effort: Tools and Institutions for Assessing Nationally Determined Contributions. Harvard Kennedy School. Available at: http://belfercenter.ksg.harvard.edu/files/evaluatingmitigation-effort-aldy_web.pdf.

${ }^{15}$ FA0 2015b. Global Forest Resources Assessment Desk Reference. Food and Agriculture Organization of the United Nations, Rome. Available at: http://www.fa0.org/3/a-i4808e.pdf; FA0. 2015 a. 
${ }^{16}$ Keenan, Rodney J., Gregory A. Reams, Frederic Achard, Joberto V. de Freitas, Alan Grainger, and Erik Lindquist. 2015. Dynamics of global forest area: Results from the FAO Global Forest Resources Assessment 2015. Forest Ecology and Management 352, 9-20.

17 UN-REDD Programme. 2016. UN-REDD Programme Collaborative Online Workspace. Accessed April 1, 2016. Available at: http://www.unredd.net/index.php?option=com_unregions\&view=overview\&ltemid=495.

18 Government of Zambia. 2015. Zambia's Intended Nationally Determined Contribution (INDC) to the 2015 Agreement on Climate Change. Available at: http://www4.unfccc.int/submissions/INDC/Published\%20 Documents/Zambia/1/FINAL+ZAMBIA'S+INDC_1.pdf.

${ }^{19}$ RRI. 2014.

20 Government of the Central African Republic. 2015. Intended Nationally Determined Contribution (INDC) (English version). Available at: http://www4.unfccc.int/submissions/INDC/Published\%20Documents/Central\%20 African\%20Republic/1/CPDN_R\%C3\%A9publique\%20Centrafricaine_EN.pdf.

${ }^{21}$ Oxfam, ILC, and RRI. 2016. Common Ground: Securing Land Rights and Safeguarding the Earth. Oxfam, International Land Coalition, and the Rights and Resources Initiative. Available at: http://www.landrightsnow. org/en/common-ground/.

* This brief was prepared by Chloe Ginsburg and Alain Frechette, with research support from Jenae Poe. Important contributions to the analysis and production of this brief were made by Andy White, Rodney Schmidt, Ilona Coyle, Jenna DiPaolo Colley, and Lindsay Bigda. 


\section{THE RIGHTS AND RESOURCES INITIATIVE}

RRI is a global coalition of 13 Partners and over 150 international, regional, and community organizations advancing forest tenure, policy, and market reforms. RRI leverages the strategic collaboration and investment of its Partners and Collaborators around the world by working together on research, advocacy, and convening strategic actors to catalyze change on the ground.

RRI is coordinated by the Rights and Resources Group, a non-profit organization based in Washington, D.C. For more information, please visit www.rightsandresources.org.

\section{PARTNERS}
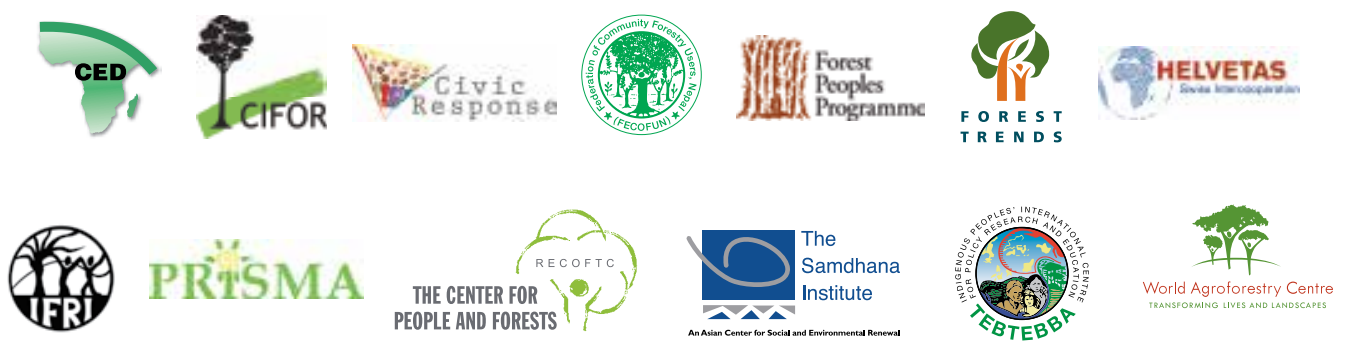

\section{SPONSORS}
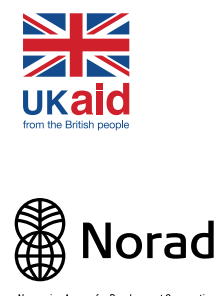
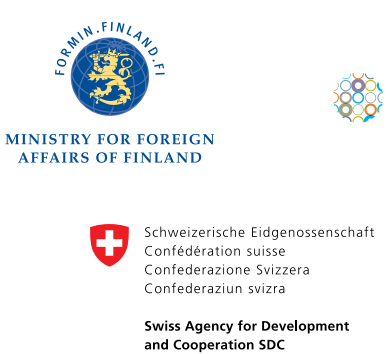

FORDFOUNDATION

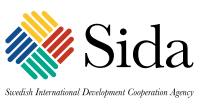

The views presented here are not necessarily shared by the agencies that have generously supported this work, or all of the Partners of the Coalition.

This work is licensed under a Creative Commons Attribution License CC BY 4.0.

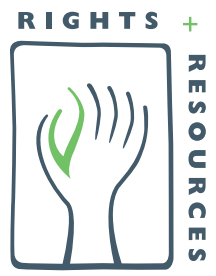

1238 Wisconsin Avenue NW

Suite 300

Washington, DC 20007

www.rightsandresources.org 